\title{
Penerapan Metode Certainty Factor pada Sistem Pakar Penentuan Minat dan Bakat Siswa SD
}

\author{
Rizal Rachman ${ }^{1 *}$, Amirul Mukminin ${ }^{2}$ \\ Program Studi Sistem Informasi \\ ${ }^{1}$ STMIK Nusa Mandiri Jakarta \\ Jakarta \\ ${ }^{2}$ AMIK Bina Sarana Informatika \\ Tasikmalaya \\ *Rizal.rzc@bsi.ac.id
}

\begin{abstract}
Abstrak-Perkembangan adalah proses kedewasaan seseorang untuk mengembangkan kemampuan intelektualnya. Perkembangan usia 6-12 tahun adalah masa di mana anak memasuki tahap belajar di dalam sekolah dan di luar sekolah. Penentuan minat dan bakat perlu dilakukan untuk dapat mengetahui suatu keterampilan pada peserta didik, baik dalam segi akademis maupun kepribadian. Selain itu juga dilakukan pendampingan dan pengembangan keterampilan sesuai bakat yang ada pada peserta didik. Untuk mengetahui bakat dan minat pada peserta didik sekolah dasar dengan salah satu cara alternatif yaitu dibuat aplikasi sistem pakar penentuan minat dan bakat pada siswa sekolah dasar berbasis web, dengan adanya aplikasi sistem pakar tersebut, dapat membantu mengetahui bakat dan minat yang dimiliki pada peserta didik sekolah dasar. Dalam merancang sistem pakar ini menggunakan sebuah metode yaitu Certainty Factor atau faktor kepastian, merupakan suatu metode untuk membuktikan apakah suatu fakta itu pasti ataukah tidak pasti yang berbentuk metric yang biasanya digunakan dalam sistem pakar. Informasi yang dihasilkan yaitu dapat menentukan jenis minat dan bakat berdasarkan ciri-ciri dan metode certainty factor juga dapat dijadikan alternatif dalam melakukan perhitungan terhadap penentuan minat dan bakat. Hasil uji konsultasi yang didapat dengan sistem ini menerangkan bahwa sistem mampu menentukan jenis kecerdasan minat dan bakat pada siswa sekolah dasar beserta informasi tentang jenis, berdasarkan ciri-ciri yang sebelumnya dipilih oleh pengguna dan informasi tentang stimulasi jenis minat dan bakat.
\end{abstract}

Kata kunci: sistem pakar, kecerdasan, minat dan bakat, certainty factor

\section{Pendahuluan}

Perkembangan adalah proses kedewasaan seseorang untuk mengembangkan kemampuan intelektualnya. Perkembangan usia 6-12 tahun adalah masa di mana anak memasuki tahap belajar di sekolah dan di luar sekolah. Anak secara formal belajar di sekolah sehingga menumbuhkembangkan terutama kemampuan kognitifnya. Selain itu anak melakukan berbagai hal di lingkungan rumah yang menumbuhkembangkan kemampuan sosial dan motoriknya. Banyak aspek perilaku pada usia tersebut yang di bentuk melalui penguatan verbal, keteladanan, dan identifikasi. Faktor yang mempengaruhi perkembangan anak tersebut adalah perkembangan fisik dan perkembangan kognitif [1].

Penentuan minat dan bakat perlu dilakukan untuk dapat mengetahui potensi peserta didik, baik dalam segi akademis maupun non-akademis. Pengetahuan itu diperlukan saat memberikan pendampingan dan pengembangan keterampilan yang sesuai bakat yang dimiliki. Keterampilan perlu dikembangkan sejak dini untuk dapat mengoptimalkan bakat yang ada pada peserta didik, sehingga dapat bersaing setelah lulus sekolah dalam kehidupan nyata terutama di dunia kerja. Penentuan bakat dan minat dapat memetakan arah pemilihan studi dan pengembangan diri untuk mendapatkan kompetensi dan keterampilan yang dibutuhkan oleh peserta didik.
Berdasarkan hasil penentuan bakat dan minat yang dilakukan, guru dapat mengelompokkan peserta didik sehingga lebih mudah untuk menentukan perlakuan dalam mengembangkan bakat dan minat yang dimiliki [2]. Peserta didik dapat pula mengetahui potensi diri dan melihat kelebihan dan kekurangan sehingga dapat mengoptimalkan pengembangan potensinya.

Peserta didik tingkat sekolah dasar berada pada peralihan ke dunia nyata yaitu ketika kemampuan kognitif anak berkembang untuk merencanakan sesuatu [3]. Usia siswa sekolah dasar yang lebih lanjut (usia 9-12 tahun) merupakan masa perkembangan keterampilan dan kreativitas serta intelegensi yang sangat pesat. Peran orang tua, guru, dan lingkungan sangat penting bagi perkembangan keterampilan dan kreativitas serta intelegensi anak di usia tersebut. Tanpa bimbingan dan dukungan dari ketiga pihak tersebut maka anak tidak dapat berkembang dengan optimal dan baik [4].

Banyak orang tua dan guru di Indonesia yang tidak mengetahui bakat dan minat anak atau tidak mengembangkan bakat yang dimiliki pada peserta didik. Perkembangan bakat peserta didik menjadi terhambat karena para orang tua dan guru tidak memberikan bimbingan khusus sesuai bakat yang dimiliki. Pengetahuan tentang minat dan bakat secara dini menjadi esensial demi pengembangan potensi peserta didik secara optimal. 
Tabel 1. Tabel daftar jenis minat dan bakat

\begin{tabular}{|c|c|c|}
\hline \multicolumn{3}{|c|}{ Daftar Jenis Minat dan Bakat } \\
\hline Kode & Nama & Bidang/Profesi \\
\hline MB1 & Linguistik & $\begin{array}{l}\text { Penulis, Wartawan, Penyair, } \\
\text { Pengacara, pembicara, } \\
\text { Politikus }\end{array}$ \\
\hline MB2 & $\begin{array}{l}\text { Logika- } \\
\text { Matematika }\end{array}$ & $\begin{array}{l}\text { Akuntan, } \\
\text { Matematika, } \\
\text { Programmer }\end{array}$ \\
\hline MB3 & Visual-Spasial & $\begin{array}{l}\text { Pelukis, Design, Navigator, } \\
\text { Arsitek }\end{array}$ \\
\hline MB4 & Kinestetik & $\begin{array}{l}\text { Aktor/Aktris, Model, Atlet, } \\
\text { Penari }\end{array}$ \\
\hline MB5 & Musikal & $\begin{array}{l}\text { Musisi, Seniman, Penyanyi, } \\
\text { Budayawan }\end{array}$ \\
\hline MB6 & Interpersonal & $\begin{array}{l}\text { Sosiologi, Public Relation, } \\
\text { Pengusaha, Pemuka Agama, } \\
\text { Pramuniaga, Para Pendidik }\end{array}$ \\
\hline MB7 & Intrapersonal & $\begin{array}{l}\text { Psikolog, Konselor, Trainer, } \\
\text { Motivator }\end{array}$ \\
\hline MB8 & Naturalis & $\begin{array}{l}\text { Antropolog, Arkeolog, } \\
\text { Meteorolog, Neorolog }\end{array}$ \\
\hline MB9 & Eksistensial & Teolog, Filsuf \\
\hline
\end{tabular}

Tulisan ini mendeskripsikan upaya untuk menentukan bakat dan minat pada peserta didik sekolah dasar dengan menggunakan aplikasi yang menerapkan sistem pakar. Penerapan sistem pakar dimaksudkan untuk meniru cara dan perilaku pakar dalam melakukan sebuah tindakan atau mengambil sikap. Penggunaan aplikasi dengan sistem pakar dapat menghemat biaya dalam hal pakar tidak tersedia, atau jumlahnya tidak memadai. Aplikasi yang dibangun menggunakan metode certainty factor, yang mencoba melihat apakah sebuah fakta bersifat pasti atau tidak pasti. Metode tersebut digunakan karena dapat memberikan hasil yang akurat yang didapatkan dari perhitungan berdasarkan bobot gejala yang dipilih oleh pakar, mampu memberikan jawaban pada permasalahan yang tidak pasti. Metode ini memperhitungkan faktor tingkat keyakinan seorang pakar dengan memberikan bobot keyakinan sesuai dengan pengetahuan pakar [5].

Metode certainty factor ini telah dicermati oleh peneliti lain untuk berbagai pengamatan dan penerapan. Penerapan metode ini berhasil dalam proses penentuan jurusan di SMA berdasarkan nilai akademik dan tes psikologi [6]. Di bidang kedokteran, penerapan metode certainty factor berhasil mendeteksi penyakit akibat kekurangan gizi pada usia produktif [7], dan penentuan penyait kulit dan kelamin [8], mendiagnosis penyakit infeksi saluran pernapasan atas [9], diagnosis penyakit pada ayam broilen [10], dan penentuan tingkat depresi dan gangguan kejiwaan [11].

\section{Metode}

\section{a. Teknik Pengumpulan Data}

Teknik pengumpulan data dilakukan untuk mencari dan mengumpulkan data agar dapat diolah menjadi informasi yang bermanfaat. Metode yang digunakan sebagai berikut:

1) Observasi

Penulis melakukan pengamatan secara langsung di

Sekolah Dasar Negeri 044 Cicadas Awigombong dengan memberikan pertanyaan atau kuisioner kepada guru serta orang tua murid untuk mendapatkan informasi yang berhubungan dalam penulisan skripsi. Dari hasil pengamatan tersebut dapat didokumentasikan secara digital dan tertulis oleh penulis.

2) Wawancara

Dalam penulisan skripsi ini, untuk mendapatkan informasi data yang lengkap dan akurat maka penulis melakukan suatu metode tanya jawab pada guru yang berhubungan dengan bakat di Sekolah Dasar Negeri 044 Cicadas Awigombong dan dengan pakar di bidang psikologi yang meliputi tentang bakat dan minat.

3) Studi Pustaka

Selain melakukan kegiatan pengumpulan data di atas, penulis juga mengambil data dari buku, jurnal, e-book serta sumber-sumber lainnya seperti laman web, artikel dan dokumen yang berkaitan dengan materi skripsi.

\section{b. Model Pengembangan Sistem}

Pada penulisan ini penulis menggunakan metode certainty factor sebagai model inferensi untuk membangun aplikasi sistem pakar ini. Penerapan certainty factor sendiri yaitu:

1) Analisis kebutuhan software

Kebutuhan software adalah kemampuan yang dimiliki oleh perangkat lunak untuk memenuhi apa yang disyaratkan atau diinginkan oleh pemakai atau user.

2) Design

Pada tahap design penulis mulai membangun aplikasi sesuai kebutuhan serta perangkat yang akan digunakan dalam implementasi aplikasi sistem pakar ini.

3) Code Generation

Dari desain yang telah dibangun, penulis memasukkan rancangan tersebut ke dalam bahasa pemrograman melalui proses coding, tahapan ini adalah bagian implementasi dari tahapan sebelumnya, yaitu tahapan desain.

4) Testing

Menjadi sebuah keharusan menguji coba sebuah aplikasi sebelum digunakan, demikian juga dengan aplikasi sistem pakar ini harus melalui tahapan pengujian, supaya aplikasi bebas dari bug atau error. Sehingga aplikasi benar-benar memenuhi kebutuhan dari pemakai.

5) Maintenantce

Pemeliharan suatu perangkat lunak sangat diperlukan, termasuk pengembangan dari aplikasi tersebut.

\section{c. Basis Pengetahuan}

Pada penelitian ini basis pengetahuan yang diperoleh dengan cara tinjauan pustaka dari buku, artikel, observasi pakar dan melakukan penelitian-penelitian terdahulu yang membahas tentang penentuan kecerdasan minat dan bakat pada siswa SD.

Pada sistem pakar penentuan minat dan bakat ini memiliki 9 jenis minat dan bakat dan ada 66 ciri-ciri yang meliputi minat dan bakat, berikut adalah daftar jenis kecerdasan minat dan bakat dijelaskan pada Tabel 1 beserta ciri-cirinya dijelaskan pada Tabel 2 dan stimulasi pada 9 jenis kecerdasan minat dan bakat pada dijelaskan Tabel 3. 
Tabel 2. Tabel daftar ciri-ciri minat dan bakat

Daftar Ciri-Ciri Minat dan Bakat

\begin{tabular}{|c|c|}
\hline Kode & Ciri-ciri \\
\hline $\mathrm{C} 1$ & Suka membaca \\
\hline $\mathrm{C} 2$ & Suka menulis \\
\hline C3 & Suka bercerita \\
\hline C4 & Suka berbicara \\
\hline C5 & Mudah memahami kata-kata baru \\
\hline C6 & Suka berdebat dengan orang lain \\
\hline $\mathrm{C} 7$ & Suka berpidato \\
\hline $\mathrm{C} 8$ & Suka menghitung angka \\
\hline C9 & $\begin{array}{l}\text { Lebih suka menerangkan tujuan } \\
\text { dengan menggunakan gambar }\end{array}$ \\
\hline C10 & Suka bermain catur \\
\hline C11 & Suka berpikir secara ilmiah \\
\hline C12 & Suka melakukan penelitian \\
\hline C13 & Suka menggunakan rumus \\
\hline C14 & Suka berhitung \\
\hline C15 & Mudah memahami cerita \\
\hline C16 & Suka melukis \\
\hline C17 & $\begin{array}{l}\text { Suka bermain dengan bentuk dan } \\
\text { ruang }\end{array}$ \\
\hline C18 & Suka memotret \\
\hline C19 & Suka bermain puzzle \\
\hline $\mathrm{C} 20$ & Mudah mengenali bentuk \\
\hline C21 & Suka melamun dan berkhayal \\
\hline $\mathrm{C} 22$ & Suka membuat sketsa \\
\hline $\mathrm{C} 23$ & Suka senam \\
\hline $\mathrm{C} 24$ & Suka menari \\
\hline $\mathrm{C} 25$ & $\begin{array}{l}\text { Aktif dalam kegiatan fisik, seperti: } \\
\text { berenang }\end{array}$ \\
\hline $\mathrm{C} 26$ & Suka olahraga bela diri \\
\hline $\mathrm{C} 27$ & Suka bermain drama \\
\hline C28 & Suka menirukan gerak \\
\hline C29 & $\begin{array}{l}\text { Menonjol dalam mata pelajaran } \\
\text { olahraga }\end{array}$ \\
\hline C30 & Suka memainkan alat musik \\
\hline C31 & Suka menyanyi \\
\hline C32 & Suka mendengarkan lagu \\
\hline C33 & Bisa menciptakan lagu \\
\hline C34 & Mudah memahami irama lagu \\
\hline C35 & Mengikuti kegiatan paduan suara \\
\hline C36 & Bisa memainkan alat musik \\
\hline C37 & $\begin{array}{l}\text { Lebih dapat belajar dengan iringan } \\
\text { lagu }\end{array}$ \\
\hline
\end{tabular}

Daftar Ciri-Ciri Minat dan Bakat

\begin{tabular}{|c|c|}
\hline Kode & Ciri-ciri \\
\hline C38 & $\begin{array}{l}\text { Suka memberikan saran kepada } \\
\text { orang lain }\end{array}$ \\
\hline C39 & Suka melakukan diskusi \\
\hline C40 & $\begin{array}{l}\text { Senang berada di antara banyak } \\
\text { orang }\end{array}$ \\
\hline C41 & $\begin{array}{l}\text { Senang berkenalan dengan orang } \\
\text { baru }\end{array}$ \\
\hline C42 & $\begin{array}{l}\text { Mampu menjadi pemimpin bagi } \\
\text { orang lain }\end{array}$ \\
\hline C43 & Senang mendengarkan orang lain \\
\hline C44 & $\begin{array}{l}\text { Suka mengajarkan sesuatu hal yang } \\
\text { baru kepada orang lain }\end{array}$ \\
\hline C45 & Mudah mengendalikan emosi \\
\hline C46 & Suka dengan keadaan yang tenang \\
\hline C47 & $\begin{array}{l}\text { Selalu merencanakan sesuatu di } \\
\text { agenda pribadi }\end{array}$ \\
\hline C48 & Mudah mengekpresikan keadaan \\
\hline C49 & $\begin{array}{l}\text { Suka merenung atau berpikir } \\
\text { tentang kehidupan atau diri sendiri }\end{array}$ \\
\hline C50 & $\begin{array}{l}\text { Belajar atau bekerja dengan baik } \\
\text { seorang diri }\end{array}$ \\
\hline C51 & $\begin{array}{l}\text { Memiliki rasa percaya diri yang } \\
\text { tinggi }\end{array}$ \\
\hline C52 & Suka merawat tanaman \\
\hline C53 & Suka memelihara binatang \\
\hline C54 & Senang bertamasya ke alam terbuka \\
\hline C55 & Suka bertani \\
\hline C56 & Suka berkebun \\
\hline C57 & Suka mengoleksi bebatuan \\
\hline C58 & $\begin{array}{l}\text { Menonjol dalam mata pelajaran IPA } \\
\text { atau lingkungan hidup }\end{array}$ \\
\hline C59 & Suka berkemah \\
\hline C60 & $\begin{array}{l}\text { Mempertanyakan keberadaan peran } \\
\text { diri sendiri di alam dunia }\end{array}$ \\
\hline C61 & Memiliki kesadaran diri yang tinggi \\
\hline C62 & $\begin{array}{l}\text { Lebih cenderung mengutamakan } \\
\text { kepentingan keyakinan atau agama }\end{array}$ \\
\hline C63 & Termotivasi secara internal \\
\hline C64 & $\begin{array}{l}\text { Memiliki kasih sayang yang tinggi } \\
\text { terhadap sesama }\end{array}$ \\
\hline C65 & Lebih tenang dan menguasai diri \\
\hline C66 & Teguh dalam kesulitan \\
\hline
\end{tabular}


Tabel 3. Tabel stimulasi minat dan bakat

\section{Minat dan \\ Bakat}

\section{Stimulasi}

- Adakah waktu saling bercerita bersama keluarga sehingga dapat melatih kemampuan berbicara dan mendengarkan anak serta libatkan anak untuk memberi pendapat.

- Sering lakukan permainan kata-kata, seperti teka-teki, scrabble, plesetan atau pantun yang dikarang sendiri.

Lingustik - Mengikutkan anak belajar bahasa asing yang diminatinya.

- Jika anak suka berdebat, bergabunglah dengan tim debat di sekolah (jika ada).

- Jika anak suka menulis cerita, kembangkan potensinya dan beri motivasi bahwa ia bisa menjadi penulis, misalnya dengan memperlihatkan karangan buku-buku untuk anak.

- Motivasi anak untuk membaca banyak hal.

- Melakukan permainan yang menggunakan strategi atau logika, seperti catur, game yang mengasah otak komputer, dll.

- Baca buku dan tonton program TV atau video tentang ilmu pengetahuan.

Logika -

Matematika

Visual -

Spasial

Kinestetik

Musikal
- Lakukan eksperimen atau percobaan ilmiah (sains) sehingga melatih logika dan kreativitas anak.

- Anak dapat menggunakan komputer, namun tidak hanya sebatas games atau internet, tetapi mempelajari cara kerja program di komputer.

- Latih ananda untuk melakukan perhitungan matematika dimulai dari yang sederhana dalam benak/pikiran (tanpa alat bantu, seperti kalkulator atau kertas).

- Kunjungi pameran atau museum ilmu pengetahuan.

- Melakukan permainan yang melibatkan gambar atau bentuk tiga dimensi, seperti, kubus rubik, lego, maze, dll.

- Ajarkan anak menguasai program komputer yang berhubungan dengan kemampuan visual, seperti menggambar atau mengedit foto di komputer.

- Fasilitas dan ikut sertakan anak les gambar, lukis atau fotografi (sesuai minat anak).

- Motivasi ananda untuk mengikuti kegiatan atau lomba yang berhubungan dengan minatnya (menggambar, melukis atau fotografi).

- Fokus mendalami bidang kinestetik (berhubungan dengan keterampilan tubuh) yang diminati, misalnya olahraga (bola, voli, basket, dan lainnya), menari atau seni yang melibatkan keterampilan tangan (mengukir, kaligrafi, masak, atau lainnya).

- Bergabung dengan tim ektrakulikuler yang berhubungan dengan bidang kinestetik yang diminati.

- Jika anak berminat dengan acting, cobalah mengikuti kursus drama (acting) dan ikut bermain sandiwara.

- Ambilah kursus seni bela diri.

- Anak dapat belajar dengan diiringi oleh musik (jika tidak merasa terganggu).

- Fokus mempelajari salah satu instrumen musik yang diminati.

- Mendengarkan sebanyak mungkin jenis-jenis musik.

- Libatkan diri dalam kegiatan musik sekolah

- Dukung anak untuk belajar musik lebih dalam.

- Tingkatkan kepercayaan diri anak dengan memuji usaha yang telah dilakukannya serta tidak merendahkan (mengejek) sifat dan perilakunya.

- Dorong anak untuk berkenalan dan bekerja sama dengan banyak orang.

- Dukung anak agar suka membantu dan berempati terhadap orang lain.

- Motivasi anak agar mau terlibat dalam kegiatan di sekolah atau di rumah.

- Latih kemampuan kepemimpinan anak dengan membiasakannya memimpin, mengatur suatu kegiatan atau ikut dalam organisasi sekolah. 


\section{Minat dan \\ Bakat}

\section{Stimulasi}

- Latih anak untuk membuat rencana masa depan atau tujuan-tujuan yang ingin dicapainya (mulai dari hal kecil, misalnya ingin nilai rapor meningkat, dll) dan ditempel di dinding kamarnya.

- Bantu anak untuk belajar mengenali kelebihan dan kelemahan dirinya (secara membangun dan tidak merendahkan) sehinggs ia lebih mengenal diri dan mengembangkan potensinya.

- Anak dapat membaca buku tentang pengembangan diri (seperti biografi atau berpikir positif, dil).

- Biasakan anak untuk merenungkan apa yang terjadi setiap harinya untuk dijadikan pelajaran, (peristiwa yang terjadi, hal yang tidak berjalan lancar, dll).

- Biasakan anak menulis tiga hal yang membuatnya merasa bersyukur atau senang setiap harinya.

- Mempelajari tentang alam (hewan, tumbuhan atau gejala alam) dengan membaca buku, majalah, program tv atau video.

- Memelihara atau merawat hewan atau tanaman.

Naturalis - Mengunjungi tempat-tempat, seperti kebun binatang, taman bunga atau tempat alam lainnya sehingga anak mendapatkan informasi dan belajar tentang alam secara langsung.

- Libatkan anak dalam organisasi lingkungan atau kegiatan 'penghijauan' sekolah atau lingkungan.

- Latih kemampuan anak di wilayah kosmos dilakukan dengan sendiri di alam terbuka dan bercakap-cakap.

- Latih kepekaan memaknai hidup dilakukan dengan bercakap-cakap, tulis buku harian,

Eksistensial melihat film, dan cerita intraktif.

- Membimbing anak memahami nilai ibadah dilakukan dengan pembiasaan dan dialog.

- Latih pengalaman mendalam dilakukan dengan menggambar, latihan diam, dan cerita intraktif.

\section{d. Certainty Factor}

Faktor kepastian merupakan suatu metode untuk membuktikan apakah suatu fakta itu pasti ataukah tidak pasti yang berbentuk metric yang biasanya digunakan dalam sistem pakar. Metode ini sangat cocok untuk sistem pakar yang mendiagnosis sesuatu yang belum pasti [12].

Tahapan dalam merepresentasikan data-data kualitatif:

1) Kemampuan untuk mengekspresikan derajat keyakinan sesuai dengan metode yang sudah dibahas sebelumnya.

2) Kemampuan untuk menempatkan dan mengkombinasikan derajat keyakinan tersebut dalam sistem pakar.

Dalam mengekpresikan derajat keyakinan digunakan suatu nilai yang disebut Certainty Factor (CF) untuk mengasumsikan derajat keyakinan seorang pakar terhadap suatu data. Berikut adalah formulasi dasar dari Certainty Factor:

$$
\mathrm{CF}[\mathrm{H} . \mathrm{E}]=\mathrm{MB}[\mathrm{H}, \mathrm{E}]-\mathrm{MD}[\mathrm{H}, \mathrm{E}]
$$

Keterangan:

$\mathrm{CF}=$ Certainty Factor (faktor kepastian) dalam hipotesis $\mathrm{H}$ yang dipengaruhi oleh fakta $\mathrm{E}$.

$\mathrm{MB}=$ Measure of Belief (tingkat keyakinan), adalah ukuran kenaikan dari kepercayaan hipotesis $\mathrm{H}$ dipengaruhi oleh fakta E.
$\mathrm{MD}=$ Measure of Disbelief (tingkat tidak keyakinan), adalah keyakinan dari ketidakpercayaan hipotesis dipengaruhi fakta $\mathrm{E}$.

$\mathrm{E}=$ Evidence (peristiwa atau fakta)

$\mathrm{H}=$ Hipotesis (Dugaan)

Untuk mengombinasikan dua atau lebih aturan, sistem berbasis pengetahuan dengan beberapa aturan, masing-masing darinya menghasilkan kesimpulan yang sama tetapi faktor ketidakpastiannya berbeda, maka setiap aturan dapat ditampilkan sebagai potongan bukti yang mendukung kesimpulan bersama. Untuk menghitung CF (keyakinan) dari kesimpulan diperlukan bukti pengkombinasian sebagai berikut:

$\mathrm{CF}(\mathrm{R} 1, \mathrm{R} 2)=\mathrm{CF}(\mathrm{R} 1)+[\mathrm{CF}(\mathrm{R} 2)] \times[1-\mathrm{CF}(\mathrm{R} 1)]$

Jika kita hanya menambahkan CF R1 dan R2, kepastian kombinasinya akan lebih dari 1. Memodifikasikan jumlah kepastian melalui penambahan dengan factor kepastian kedua dan mengalikannya (1 dikurangi faktor kepastian pertama). Jadi, semakin besar CF pertama semakin kecil kepastian penambahan kedua. Tetapi faktor tambahan selalu menambahkan beberapa kepastian. Untuk aturan ketiga yang ditambahkan, dapat digunakan aturan sebagai berikut [13]:

$\mathrm{CF}(\mathrm{R} 1, \mathrm{R} 2, \mathrm{R} 3)=\mathrm{CF}(\mathrm{R} 1, \mathrm{R} 2)+[\mathrm{CF}(\mathrm{R} 3)][1-\mathrm{CF}(\mathrm{R} 1, \mathrm{R} 2)]$

$=\mathrm{CF}(\mathrm{R} 1, \mathrm{R} 2)+\mathrm{CF}(\mathrm{R} 3)-[\mathrm{CF}(\mathrm{R} 1, \mathrm{R} 2)] \cdot[\mathrm{CF}(\mathrm{R} 3)$ 


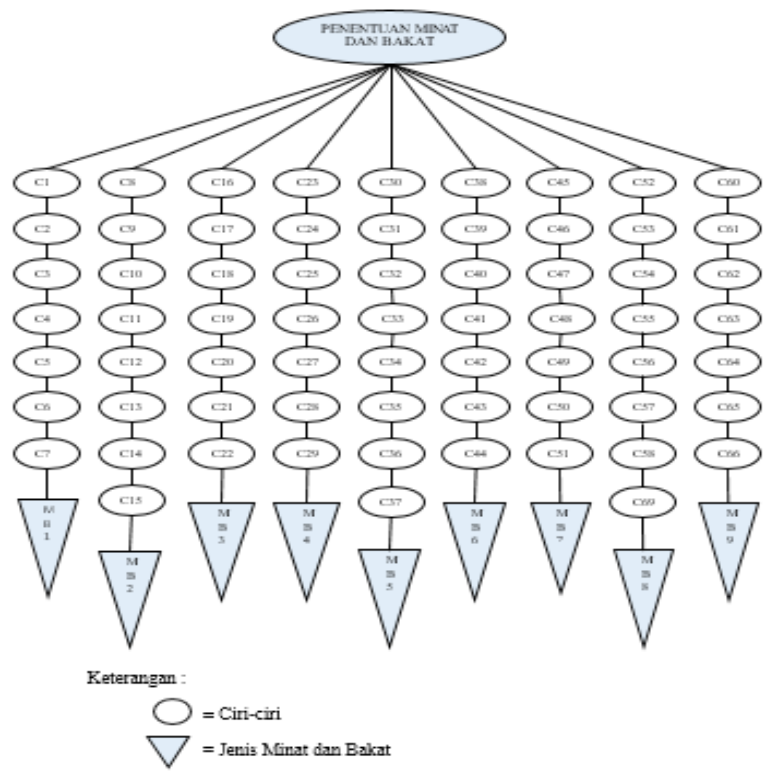

Gambar 1. Pohon keputusan pakar

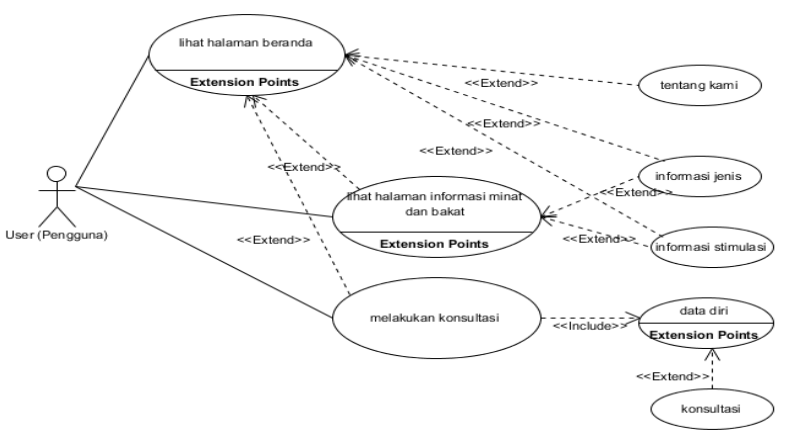

Gambar 2. Use case diagram user/pengguna

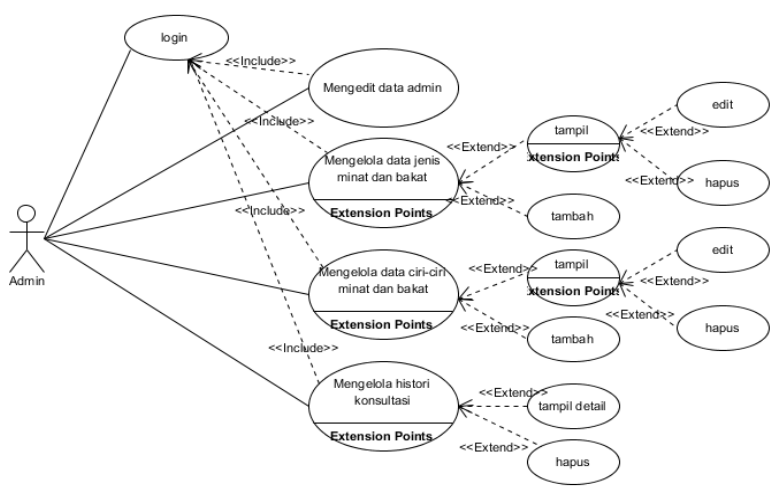

Gambar 3. Use case diagram admin

Untuk solusi dengan lebih banyak aturan dapat menggunakan persamaan yang secara bertingkat seperti pada persaman diatas.

\section{e. Pohon Keputusan Pakar}

Pohon pakar adalah suatu pohon hierarki struktur yang terdiri dari node (simpul) yang menyimpan informasi atau pengetahuan dan cabang yang menghubungkan node. Sebuah pohon keputusan dibuat untuk memudahkan dalam pengambilan keputusan. Diagram keputusan merupakan gambaran secara sederhana permasalahan dan pemecahannya. Berikut adalah pohon pakar dari kasus penentuan minat dan bakat pada siswa SD dijelaskan di Gambar 1.

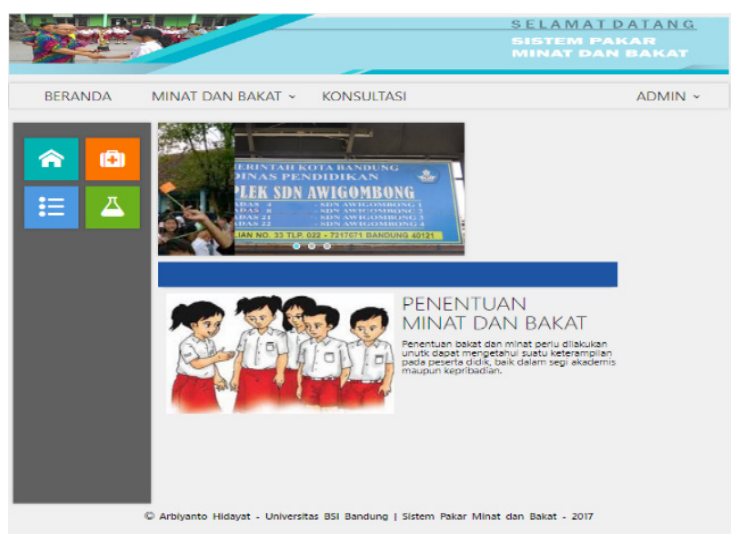

Gambar 4. Tampilan halaman beranda

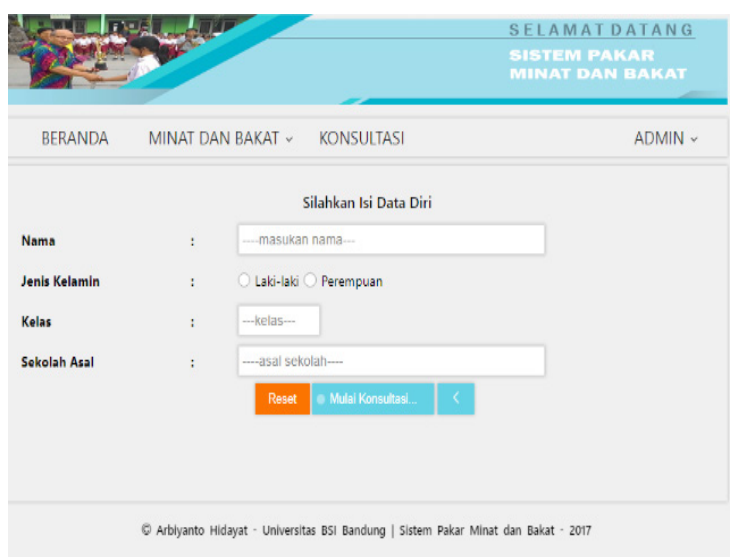

Gambar 5. Halaman data diri

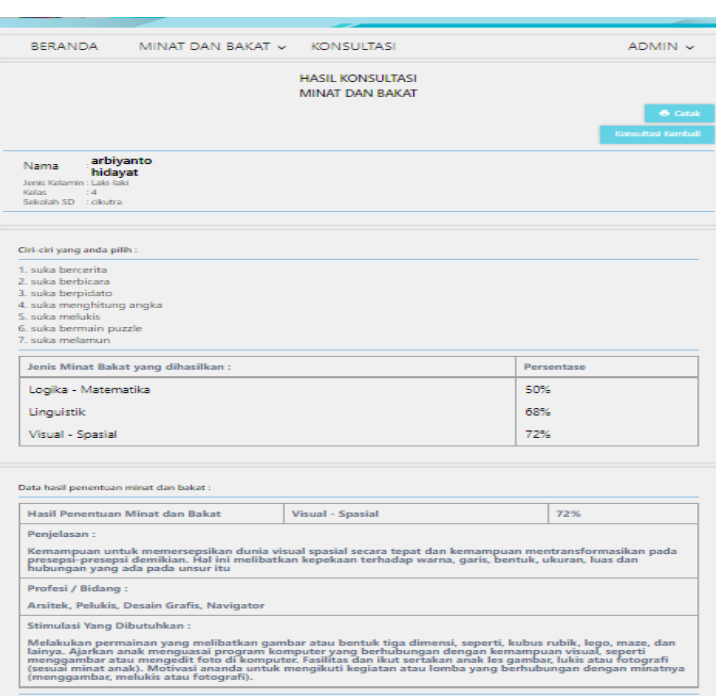

Gambar 6. Halaman hasil konsultasi

\section{Hasil dan diskusi}

Sistem pakar ini mendeteksi tingkat kecerdasan pada anak berbasis website yang dapat memudahkan dalam menentukan tingkat kecerdasan minat dan bakat anak SD menggunakan metode Certainty Factor dengan uraian implementasi sebagai berikut:

\section{a. Tahapan Analisis}

Berikut ini adalah rancangan awal dari sebuah sistem yang akan dibangun, perlu dilakukan analisa kebutuhan software, yaitu: 
1. Kebutuhan Halaman User (Pengguna):

A1 User dapat melihat halaman beranda.

A2 User dapat melihat halaman informasi minat dan bakat.

A3 User dapat melakukan konsultasi.

2. Kebutuhan Admin:

B1 Admin login

B2 Admin dapat mengelola data admin

B3 Admin dapat mengelola data jenis minat dan bakat

B4 Admin dapat mengelola data ciri-ciri minat dan bakat

B5 Admin dapat mengelola data histori konsultasi

3. Use Case Diagram

Terdapat dua aktor pada use case diagram sistem pakar menentukan kecerdasan minat dan bakat pada anak ini yaitu User/Pengguna dan Admin diuraikan pada Gambar 2. dan Gambar 3.

\section{b. Perhitungan Manual}

Untuk menjelaskan perhitungan sistem pakar penentuan minat dan bakat pada siswa SD dengan menggunakan metode certainty factor. Diuraikan dengan contoh kasus sebagai berikut.

Dalam sistem pakar menentukan jenis minat dan bakat pada siswa SD ini terdapat perhitungan dalam menentukan certainty factor. Misalkan dalam menentukan minat dan bakat siswa SD memilih beberapa contoh ciriciri di antaranya:

1) Suka membaca

2) Suka berbicara

3) Suka berpidato

Berikut c

ontoh perhitungan Certainty Factor.

Minat dan Bakat 1 (Linguistik)

Ciri - ciri $1\left[\mathrm{~h}_{1}, \mathrm{e}\right]$ : Suka membaca $\left(\mathrm{MB}\left[\mathrm{h}_{1}, \mathrm{e}\right]=0,7, \mathrm{MD}\right.$ $\left.\left[\mathrm{h}_{1}, \mathrm{e}\right]=0,4\right)$

Sehingga $C F\left[\mathrm{~h}_{1}, \mathrm{e}\right]=0,7-0,4=0,3$

Ciri - ciri $2\left[\mathrm{~h}_{2}, \mathrm{e}\right]$. Suka berbicara $\left(\mathrm{MB}\left[\mathrm{h}_{2}, \mathrm{e}\right]=0,6, \mathrm{MD}\right.$ $\left.\left[\mathrm{h}_{2}, \mathrm{e}\right]=0,4\right)$

Sehingga $C F\left[\mathrm{~h}_{2}, \mathrm{e}\right]=0,6-0,4=0,2$

Untuk mencari $\mathrm{CF}\left[\mathrm{h}_{1}{ }^{\wedge} \mathrm{h}_{2}\right.$ e] dapat diperoleh dari:

$$
\begin{aligned}
\mathrm{CF}\left[\mathrm{h}_{1} \wedge \mathrm{h}_{2,} \mathrm{e}\right] & =\mathrm{CF}\left[\mathrm{h}_{1}, \mathrm{e}\right]+\mathrm{CF}\left[\mathrm{h}_{2}, \mathrm{e}\right] *\left(1-\mathrm{CF}\left[\mathrm{h}_{1}, \mathrm{e}\right]\right) \\
& =0,3+0,2 *(1-0,3) \\
& =0,44
\end{aligned}
$$

Ciri - ciri $3\left[\mathrm{~h}_{3}, \mathrm{e}\right]$ : Suka berpidato $\left(\mathrm{MB}\left[\mathrm{h}_{3}, \mathrm{e}\right]=0,7, \mathrm{MD}\right.$ $\left.\left[\mathrm{h}_{3}, \mathrm{e}\right]=0,3\right)$

Sehingga $C F\left[\mathrm{~h}_{3}, \mathrm{e}\right]=0,7-0,3=0,5$

Untuk mencari $\mathrm{CF}\left[\mathrm{h}_{1}, \mathrm{~h}_{2}{ }^{\wedge} \mathrm{h}_{3}\right.$ e] dapat diperoleh dari:

$\mathrm{CF}\left[\mathrm{h}_{1}, \mathrm{~h}_{2}{ }^{\wedge} \mathrm{h}_{3}, \mathrm{e}\right]=\mathrm{CF}\left[\mathrm{h}_{1}, \mathrm{~h}_{2}, \mathrm{e}\right]+\mathrm{CF}\left[\mathrm{h}_{3}, \mathrm{e}\right] *(1-\mathrm{CF}$ $\left.\left[\mathrm{h}_{1,} \mathrm{~h}_{2}, \mathrm{e}\right]\right)$

$$
\begin{aligned}
& =0,44+0,5 *(1-0,44) \\
& =0,746
\end{aligned}
$$

Dari contoh tersebut dapat dilihat bahwa, faktor kepercayaan dalam kecerdasan linguistik jika memilih ketiga ciri-ciri tersebut, memberikan faktor kepastian adalah $(0,746)$.

\section{c. User Interface}

User interface digunakan untuk memberi gambaran tampilan antar muka sistem yang dibangun. Tampilan halaman beranda merupakan halaman awal pada saat pertama kali mengakses aplikasi sistem pakar penentuan minat dan bakat pada siswa SD, berikut halaman beranda User ditampilkan di Gambar 4.

Halaman konsultasi merupakan halaman yang digunakan oleh siswa SD untuk melakukan konsultasi penentuan minat dan bakat. Pada halaman konsultasi siswa harus mengisi data diri (lihat Gambar 5) dan memilih ciriciri minat dan bakat sesuai kriteria untuk selanjutnya siswa mendapatkan hasil konsultasi seperti yang ditampilkan pada Gambar 6.

\section{d. Diskusi}

Perhitungan sistem menunjukkan nilai perbandingan yang sama antara hasil perhitungan manual dan perhitungan sistem yaitu 0,746 atau $74,60 \%$. Angka ini menurut tabel interpretasi Certainy Factor menandakan bahwa nilai kebenaran mendekati hampir pasti. Artinya, pengaruh penerapan metode certainty factor dapat memberikan konstribusi untuk dapat menentukan minat dan bakat melalui ciri-ciri yang dimiliki oleh masing-masing siswa. Pengukuran oleh sistem pakar dapat memberikan hasil yang akurat sesuai yang dihasilkan oleh pakar.

Angka interprestasi yang didapat dalam penelitian ini termasuk tinggi. Penelitian oleh [14] menghasilkan kombinasi dan nilai certainty factor untuk jenis kepribadian yang dimiliki oleh user dengan tingkat kepastian 0,5742 atau dengan $57,42 \%$. Sementara itu, penelitian oleh [15] menghasilkan nilai certainty factor 0,6 atau $60 \%$. Angka ini diklaim oleh si peneliti telah menunjukkan bahwa sistem pakar yang dibangun mampu mengidentifikasi masalah yang dihadapi siswa sehingga membantu guru bimbingan konseling dalam menentukan jenis layanan yang diberikan.

Selain menggunakan certainty factor, sistem pakar dapat menerapkan berbagai algoritma yang telah ada seperti algoritma breadth-first search dan metode Dempster-Shafer. Perolehan angka interpretasi yang cukup tinggi diperoleh dalam penelitian oleh [16] yaitu sebesar 0,71 atau $71 \%$ menggunakan algoritma breadth-first search. Dengan angka interpretasi sebesar itu, peneliti mengklaim bahwa seorang pasien penyakit ginjal dapat melakukan diagnosis awal secara mandiri tanpa harus menunggu pemeriksaan oleh dokter. Penelitian oleh [17] menerapkan metode DempsterShafer yang menghasilkan bobot kepercayaan bernilai 0,81 atau $81 \%$. Para peneliti selanjutnya menyatakan bahwa hasil diagnosis kerusakan jalur komunikasi yang dihasilkan oleh aplikasi telah sesuai dengan rule yang dipilih dan ditentukan oleh teknisi ahli. 


\section{Kesimpulan}

Hasil penelitian menunjukkan bahwa aplikasi yang dikembangkan dengan menerapkan metode Certainty Factor yang telah dibuat dapat menentukan minat dan bakat berdasarkan ciri-ciri. Metode certainty factor dapat dijadikan alternatif dalam melakukan perhitungan terhadap penentuan minat dan bakat. Aplikasi sistem pakar ini dapat membantu para guru, orang tua siswa atau siswa itu sendiri dalam menentukan minat dan bakat siswa. Aplikasi memberikan informasi tentang kecerdasan, minat dan bakat baik itu jenis, ciri-ciri atau pun stimulasi minat dan bakat dengan cara yang mudah.

\section{Daftar Pustaka}

[1] J.Nurihsan and M. Agustin, Dinamika Perkembangan Anak dan Remaja. Bandung: PT. Refika Aditama, 2013.

[2] Kemdikbud, "Pengembangan Bakat dan Minat," Jakarta, p. 7, 2016.

[3] W. Yulianti, "Aptitude Testing Berbasis CaseBased Reasoning dalam Sistem Pakar untuk Menentukan Minat Dan Bakat Siswa Sekolah Dasar," J. Teknol. dan Sist. Inf. Uniurab, vol. 1, no. 2, pp. 104-118, 2016.

[4] F. N. Salisah, L. Lidya, and S. Defit, "Sistem Pakar Penentuan Bakat Anak dengan Menggunakan Metode Forward Chaining," J. Ilm. Rekayasa dan Manaj. Sist. Inf., vol. 1, no. 1, pp. 62-66, 2015.

[5] A. F. Indriani, E. Y. Rachmawati, and J. D. Fitriana, "Pemanfaatan Metode Certainty Factor dalam Sistem Pakar Diagnosa Penyakit pada Anak," Techno.Com, vol. 17, no. 1, pp. 12-22, 2018.

[6] T. A. Cikraeni and Ruliah, "Penerapan Metode Certainty Factor untuk Keputusan Pemilihan Jurusan di SMA," Progressif, vol. 9, no. 1, 2015.

[7] F. Wulandari and I. Yuliandri, "Diagnosa Gangguan Gizi Menggunakan Metode Certainty Factor," J. Sains dan Teknol. Ind., vol. 11, no. 2, pp. 305-313, 2014.
[8] I. P. B. Krisnawan, I. K. G. D. Putra, and I. P. A. Bayupati, "Sistem Pakar Diagnosa Penyakit Kulit dan Kelamin," J. Ilm. Merpati (Menara Penelit. Akad. Teknol. Informasi), 2014.

[9] L. Septiana, "Perancangan Sistem Pakar Diagnosa Penyakit Ispa dengan Metode Certainty Factor Berbasis Android," J. Techno Nusa Mandiri, vol. 13, no. 2, pp. 1-7, 2016.

[10] J. Rahmah and R. A. Saputra, "Penerapan Certainty Factor pada Sistem Pakar Diagnosa Penyakit Saluran Pencernaan Ayam Broiler," J. Inform., vol. 4, no. 1, pp. 94-102, 2017.

[11] A. Supiandi and D. B. Chandradimuka, "Sistem Pakar Diagnosa Depresi Mahasiswa Akhir Dengan Metode Certainty Factor Berbasis Mobile," J. Inform., vol. 5, no. 1, pp. 102-111, 2018.

[12] S. Kusumadewi, Artificial Intelegence (Teknik dan Aplikasinya). Yogyakarta: Graha Ilmu, 2003.

[13] M. Arhami, Konsep Dasar Sistem Pakar. Yogyakarta: Andi Offset, 2008.

[14] N. A. Putri, "Sistem Pakar untuk Mengidentifikasi Kepribadian Siswa Menggunakan Metode Certainty Factor dalam Mendukung Pendekatan Guru," INTECOMS J. Inf. Technol. Comput. Sci., vol. 1, no. 1, pp. 78-90, 2018.

[15] D. Robiyono, B. Harijanto, and R. Rismanto, "Pengembangan Aplikasi Bimbingan dan Konseling (Studi Kasus : SMA Negeri 1 Bangil)," Semin. Inform., 2016.

[16] Y. aditya Pratama and E. Junianto, "Sistem Pakar Diagnosa Penyakit Ginjal dan Saluran Kemih dengan Metode Breadth First Search," J. Inform., vol. 2, no. 1, 2016.

[17] E. Lestari and E. U. Artha, "Sistem Pakar dengan Metode Dempster Shafer untuk Diagnosis Gangguan Layanan Indihome di PT Telkom Magelang," Khazanah Inform. J. Ilmu Komput. dan Inform., vol. 3, no. 1, pp. 16-24, 2017. 